\title{
Cryopreservation of primed tobacco seeds ${ }^{1}$
}

\author{
Camila Aparecida Lopes ${ }^{2 *}$, Maria Laene Moreira de Carvalho ${ }^{2}$, Ana Cristina de \\ Souza $^{2}$, João Almir Oliveira ${ }^{2}$, Dayliane Bernardes de Andrade ${ }^{2}$
}

\begin{abstract}
Priming is a commercial technique used to increase the speed and uniformity of seed germination. However, the physiological quality of primed seeds is usually negatively affected during storage. Tobacco seeds of the cultivar BAT 2101 were used to investigate whether primed seeds could be cryopreserved. The most suitable substances, type of drying, and reheating during priming and cryopreservation of tobacco seeds were studied. Seed priming was performed with water, spermidine, and potassium nitrate, and drying was carried out with silica gel and a saturated saline solution. Seeds were cryopreserved in liquid nitrogen for $24 \mathrm{~h}$ and reheated in a water bath for two and five minutes and at ambient temperature. Tobacco seeds primed with spermidine and water can be cryopreserved without loss of physiological quality when quickly dried on silica gel and reheated in a water bath for two minutes.
\end{abstract}

Index terms: germination, emergence, Nicotiana tabacum, reheating, drying.

\section{Criopreservação de sementes de tabaco condicionadas fisiologicamente}

\begin{abstract}
RESUMO - O condicionamento fisiológico é uma técnica comercial utilizada para aumentar a velocidade e uniformidade de germinação das sementes, porém, a qualidade fisiológica das sementes condicionadas é geralmente afetada negativamente durante o armazenamento. Sementes de tabaco da cultivar BAT 2101 foram utilizadas para investigar se sementes condicionadas podem ser criopreservadas. Foram estudadas as substâncias, o tipo de secagem e o reaquecimento mais adequados durante o condicionamento e a criopreservação de sementes de tabaco. O condicionamento das sementes foi realizado com água, espermidina e nitrato de potássio, e a secagem com sílica gel e solução salina saturada. As sementes foram criopreservadas em nitrogênio líquido por $24 \mathrm{~h}$ e reaquecidas em banho-maria por dois e cinco minutos e em temperatura ambiente. Sementes de tabaco condicionadas fisiologicamente com espermidina e água podem ser criopreservadas, sem perda de sua qualidade fisiológica, quando secas rapidamente em sílica gel e reaquecidas em banho-maria por dois minutos.
\end{abstract}

Termos para indexação: germinação, emergência, Nicotiana tabacum, reaquecimento, secagem.

\section{Introduction}

Brazil stands out as one of the main exporters of tobacco (Nicotiana tabacum L.) seeds, as well as processed tobacco, serving the various markets in the world. Seeds are produced by the tobacco industry, with some being sold to tobacco producers (cooperated with companies) and part of them exported (Segato and Gabaldi, 2012). There is a demand in the tobacco market, both nationally and internationally, for good quality seeds. However, tobacco seeds present a small size and have some problems such as uneven maturation and dormancy (Majdi et al., 2012), which can affect the germination rate and uniformity of lots. An alternative to increasing the germination rate and uniformity is the use of the seed priming technique.

Seed priming aims at reducing the germination period, as well as to synchronize and improve seedling emergence, by subjecting the seeds to a sufficient hydration control to allow the metabolic processes essential to germination, but insufficient to provide radicle protrusion (Varier et al., 2010). Priming efficiency has been tested for tobacco seeds by researchers such as Wen-Guang et al. (2009), who observed

\footnotetext{
${ }^{1}$ Submitted on $07 / 09 / 2018$. Accepted for publication on 08/27/2018.

${ }^{2}$ Departamento de Agricultura, Universidade Federal de Lavras, Caixa Postal 3037, 37200-000 - Lavras, MG, Brasil.

*Corresponding author <camilalopes_sjc@hotmail.com>
} 
increases in tobacco seed germination, with an increase in the length and seedling dry weight in relation to the control. Caldeira et al. (2014) observed that priming positively affected the vigor of tobacco seed lots.

Despite the advantages of seed priming, one of the difficulties of this technique is the storage of seeds after the treatment since they lose the quality more quickly. Rodrigues et al. (2011) observed the need for studies that seek to achieve a positive effect of priming as it minimizes deleterious effects during storage. Little is known about the behavior of primed tobacco seeds after storage. Caldeira et al. (2014) stored primed tobacco seeds in a cold chamber and observed the maintenance of their physiological quality for three months.

An alternative to preserving the quality of primed seeds during storage would be the use of cryopreservation since it allows conserving the material for long periods at extremely low temperatures (Faria et al., 2016). Several studies on cryopreservation have been carried out worldwide to complement traditional seed storage methods (Veiga-Barbosa et al., 2013; Pérez-Rodrígues et al., 2017), but there are few reports on cryopreservation of seed tobacco and none on the cryopreservation of primed tobacco seeds. For instance, Touchell and Dixon (1994) were only able to regenerate plants of Nicotiana occidentalis W. from the germination of in vitro isolated embryos after cryopreservation of whole seeds and obtained low levels of propagation by means of conventional methods of propagation. Pérez-Rodrígues et al. (2017) observed the importance of reduced water contents in the cryopreservation of tobacco seeds.

This study aimed to investigate whether primed tobacco seeds can be cryopreserved. Priming substances (water, spermidine, and potassium nitrate), type of seed drying after priming (slow or fast), and the most suitable reheating after tobacco seed cryopreservation (water bath for two and five minutes and ambient temperature).

\section{Material and Methods}

The experiment was carried out with seeds of Nicotiana tabacum from the cultivar BAT 2101, Burley group. The lot characterization was performed by determining water content and germination test (according to the methodology adapted from the Rules for Seed Testing) and emergence under controlled conditions on the commercial substrate Carolina ${ }^{\circledR}$.

Tobacco seeds were submitted to priming in a solution aerated for $24 \mathrm{~h}$ in water $\left(\mathrm{H}_{2} \mathrm{O}\right)$, spermidine (SPD) at a concentration of $0.5 \mu \mathrm{mol} . \mathrm{L}^{-1}$, and potassium nitrate $\left(\mathrm{KNO}_{3}\right)$ at a concentration of $-1.0 \mathrm{MPa}$. Seeds were washed in running water after priming and then dried until reaching approximately $6.0 \%$ moisture. For this, two drying speeds were tested: fast, on silica gel, and slow, with the use of a saturated saline solution (the salt used was sodium chloride). Water loss was monitored by continuous weighing until the seeds reached the water content of interest. Seeds without priming were used as controls.

After drying, the seeds were transferred to cryotubes with a $2.0 \mathrm{~mL}$ capacity and then immersed in liquid nitrogen $\left(-196{ }^{\circ} \mathrm{C}\right)$, where they remained for $24 \mathrm{~h}$. The seeds were thawed in three different reheating methods: water bath at $38 \pm 2{ }^{\circ} \mathrm{C}$ for two minutes, water bath at $38 \pm 2{ }^{\circ} \mathrm{C}$ for five minutes, and at ambient temperature $\left(25 \pm 2{ }^{\circ} \mathrm{C}\right)$.

After drying, cryopreservation, and reheating treatments, the physiological quality tests were performed.

The germination test was conducted with four replications of 50 seeds on two sheets of paper (blotting type) moistened with distilled water equivalent to 2.5 times the dry paper weight, distributed in four gerbox plastic boxes. The seeds were maintained in a BOD (Biological Oxygen Demand) germinating chamber with alternating temperatures of 20 and $30{ }^{\circ} \mathrm{C}\left(20^{\circ} \mathrm{C}\right.$ for $8 \mathrm{~h}$ without light and $30{ }^{\circ} \mathrm{C}$ for $16 \mathrm{~h}$ with light) and light intensity above 2000 lux (Brasil, 2009). The number of germinated seeds (with protruded radicle and the first pair of expanded leaves) was assessed daily to obtain the germination rate index (Maguire, 1962). The results of germination were expressed as the percentage of normal seedlings and were assessed at seven days after sowing to obtain the first germination count and at 16 days to obtain the germination (Brasil, 2009).

The tetrazolium test was performed on the remaining seeds (treatments that obtained a germination percentage lower than $80 \%$ ). Tobacco seeds were placed in a $1 \%$ tetrazolium solution at $40{ }^{\circ} \mathrm{C}$ in the dark for $24 \mathrm{~h}$. For determining the viability, these seeds were manually sectioned and analyzed in a magnifying glass, being considered as viable those of pink or red coloration and unviable those of wine coloration or discolored.

The emergence test was conducted with four replications of 50 seeds and the sowing was carried out on the commercial substrate Carolina ${ }^{\circledR}$ previously moistened (in the ratio of $1 \mathrm{~L}$ of water per $\mathrm{kg}$ of substrate), placed in 100-cell acrylic plates, and maintained in the float system (perforated plates floating on a water slide of approximately two centimeters) at an alternating temperature of 20 and $30^{\circ} \mathrm{C}\left(20^{\circ} \mathrm{C}\right.$ for $8 \mathrm{~h}$ without light and $30^{\circ} \mathrm{C}$ for $16 \mathrm{~h}$ with light) and light intensity above 2,000 lux (Brasil, 2009). The number of seedlings with the first pair of expanded leaves was assessed daily to obtain the emergence rate index (Maguire, 1962). The counts were performed on the $7^{\text {th }}$ day in order to obtain the initial 
emergence and on the $16^{\text {th }}$ day to obtain the final emergence, being the data expressed as a percentage.

The electrical conductivity test was performed following a methodology used by Caldeira et al. (2014). Three replications of 0.1 grams of seeds were used for each treatment. The seeds were placed in individual cells of a tray and immersed in $5 \mathrm{~mL}$ of deionized water for $12 \mathrm{~h}$ at a controlled temperature of $25^{\circ} \mathrm{C}$. Conductivity was performed with a benchtop conductivity meter for aqueous solutions. The data were expressed in $\mu \mathrm{S} . \mathrm{cm}^{-1} \cdot \mathrm{g}^{-1}$.

The seeds were submitted to priming, drying, and reheating using a completely randomized design in a factorial scheme (3 $\times 2 \times 3$ ), with three forms of priming $\left(\mathrm{H}_{2} \mathrm{O}, \mathrm{SPD}\right.$, and $\mathrm{KNO}_{3}$ ), two forms of drying the seeds after priming (slow and fast), and three methods of reheating after cryopreservation (water bath for two and five minutes and at ambient temperature). The means were submitted to analysis of variance and the results were analyzed by mean comparison using the Scott-Knott test at $5 \%$ probability in the software Sisvar ${ }^{\circledR}$ (Ferreira, 2011).

\section{Results and Discussion}

A water content of $6.02 \%$, germination of $93 \%$, and emergence of $83 \%$ were observed in the characterization of the tobacco seed lot of the cultivar BAT 2101. The established standard for the commercialization of tobacco seeds is at least $80 \%$ of germination (Brasil, 2013).

The values obtained for the water content of seeds after priming application and drying are shown in Table 1. A small oscillation in seed moisture was observed due to the water restriction caused by the conditioning agents, with the lowest absorption provided by the restriction with the use of spermidine (SPD).

In the analysis of variance, the triple interaction between the factors priming, drying, and reheating of seeds after cryopreservation was significant. Thus, the efficiency of the cryopreservation technique of primed tobacco seeds depends on the interaction of the substance used for seed priming, seed drying method after priming, and the reheating method after cryopreservation for all the analyzed variables: electrical conductivity, first germination count, germination, germination rate index, initial and final emergence, and emergence rate index.

Primed seeds with potassium nitrate $\left(\mathrm{KNO}_{3}\right)$ presented a higher electrical conductivity when compared to the others (Table 2A). According to Reis et al. (2012), this behavior is related to the absorption of $\mathrm{K}^{+}$and ions such as $\mathrm{NO}_{3}{ }^{-}$during priming and subsequent release of these elements in the soaking water, increasing the electrical conductivity values of seeds. Regarding the reheating method after cryopreservation, a variation was observed for conductivity.
A slow drying provided to the primed and cryopreserved seeds a higher solute leaching and consequently a higher electrical conductivity when compared to the fast drying (Table 2B). According to Caseiro and Marcos-Filho (2005), cells naturally tolerant to desiccation, when maintained with moisture levels associated with the occurrence of metabolic activities, may suffer more severe damage if they remain under these conditions for a long period when compared to those dried quickly.

Table 1. Water content (\%) of tobacco (Nicotiana tabacum) seeds of the cultivar BAT2101 after different forms of priming and drying.

\begin{tabular}{cccc}
\hline \multirow{2}{*}{ Priming } & \multirow{2}{*}{ Drying } & \multicolumn{2}{c}{ Water content (\%) } \\
\cline { 3 - 4 } & & After priming & After drying \\
\hline Water & Slow & 55.49 & 6.20 \\
Water & Fast & 55.49 & 6.10 \\
\hline SPD & Slow & 54.51 & 6.07 \\
SPD & Fast & 54.51 & 5.93 \\
\hline $\mathrm{KNO}_{3}$ & Slow & 55.39 & 6.31 \\
$\mathrm{KNO}_{3}$ & Fast & 55.39 & 6.11 \\
\hline Control & - & - & 6.00 \\
\hline
\end{tabular}

Table 2. Electrical conductivity $\left(\mu \mathrm{S} . \mathrm{cm}^{-1} \cdot \mathrm{g}^{-1}\right)$ of primed and cryopreserved tobacco (Nicotiana tabacum) seeds of the cultivar BAT 2101 for the factors priming and reheating $(\mathrm{A})$ and drying $(\mathrm{B})$.

\begin{tabular}{|c|c|c|c|c|}
\hline \multicolumn{5}{|c|}{$\mathrm{A}$} \\
\hline \multirow{2}{*}{ Priming } & \multirow{2}{*}{ Drying } & \multicolumn{3}{|c|}{ Reheating } \\
\hline & & Ambient temp & WB: 2 min & WB: $5 \mathrm{~min}$ \\
\hline Water & Slow & $181.68 \mathrm{bC}$ & $152.95 \mathrm{aB}$ & $147.40 \mathrm{aA}$ \\
\hline SPD & Slow & $148.44 \mathrm{aA}$ & $221.02 \mathrm{bC}$ & $264.62 \mathrm{bC}$ \\
\hline $\mathrm{KNO}_{3}$ & Slow & $551.40 \mathrm{cC}$ & $426.02 \mathrm{cA}$ & $485.94 \mathrm{cB}$ \\
\hline Water & Fast & $155.00 \mathrm{aB}$ & $147.13 \mathrm{aA}$ & $237.70 \mathrm{bC}$ \\
\hline SPD & Fast & $165.19 \mathrm{bB}$ & $156.38 \mathrm{bA}$ & $186.61 \mathrm{aC}$ \\
\hline $\mathrm{KNO}_{3}$ & Fast & $427.34 \mathrm{cA}$ & $510.92 \mathrm{cB}$ & $545.81 \mathrm{cC}$ \\
\hline \multicolumn{5}{|c|}{$\mathrm{B}$} \\
\hline \multirow{2}{*}{\multicolumn{2}{|c|}{ Priming }} & \multirow{2}{*}{ Reheating } & \multicolumn{2}{|c|}{ Drying } \\
\hline & & & Slow & Fast \\
\hline Water & & Ambient temp & $181.68 \mathrm{~B}$ & $155.00 \mathrm{~A}$ \\
\hline Water & & WB: 2 min & $152.95 \mathrm{~B}$ & $147.13 \mathrm{~A}$ \\
\hline Water & & WB: 5 min & $147.40 \mathrm{~A}$ & $237.70 \mathrm{~B}$ \\
\hline SPD & & Ambient temp & $148.44 \mathrm{~A}$ & $165.19 \mathrm{~B}$ \\
\hline SPD & & WB: 2 min & $221.02 \mathrm{~B}$ & $156.38 \mathrm{~A}$ \\
\hline SPD & & WB: 5 min & $264.62 \mathrm{~B}$ & $186.61 \mathrm{~A}$ \\
\hline $\mathrm{KNO}_{3}$ & & Ambient temp & $551.40 \mathrm{~B}$ & $427.34 \mathrm{~A}$ \\
\hline $\mathrm{KNO}_{3}$ & & WB: 2 min & $426.02 \mathrm{~A}$ & $510.92 \mathrm{~B}$ \\
\hline $\mathrm{KNO}_{3}$ & & WB: 5 min & $485.94 \mathrm{~A}$ & $545.81 \mathrm{~B}$ \\
\hline \multicolumn{5}{|c|}{$\mathrm{CV}(\%)=5.73$} \\
\hline
\end{tabular}

Means followed by the same lowercase letter in the column and uppercase letter in the row do not differ by Scott-Knott test at 5\% probability level. 
Seeds primed with $\mathrm{KNO}_{3}$ and dried slowly presented a lower percentage of normal seedlings at the first germination count than seeds primed with SPD or water (Table 3A). Primed, dried, and cryopreserved seeds, when reheated at ambient temperature or water bath for two minutes, presented a higher percentage of normal seedlings than those reheated in a water bath for five minutes. However, Pérez-Rodríguez et al. (2017) used in their study the reheating of cryopreserved tobacco seeds in a water bath for five minutes with success.

In addition, seeds submitted to a fast drying give rise to a higher number of normal seedlings than those submitted to a slow drying (Table 3B).

In the germination, a lower percentage of normal seedlings was observed for seeds primed with potassium nitrate and dried slowly, regardless of the reheating method. The percentage of normal seedlings is also low when the seeds are primed with spermidine, dried slowly after priming, and reheated in a water bath for five minutes (Table 4A).

Seeds subjected to a fast drying showed a higher percentage of normal seedlings at the end of the germination test when compared to those submitted to a slow drying (Table 4B), showing that the fast drying of tobacco seeds for cryopreservation is more

Table 3. First germination count (\%) of primed and cryopreserved tobacco (Nicotiana tabacum) seeds of the cultivar BAT 2101 for the factors priming and reheating $(\mathrm{A})$ and drying $(\mathrm{B})$.

\begin{tabular}{|c|c|c|c|c|}
\hline \multicolumn{5}{|c|}{ A } \\
\hline \multirow{2}{*}{ Priming } & \multirow{2}{*}{ Drying } & \multicolumn{3}{|c|}{ Reheating } \\
\hline & & Ambient temp & WB: 2 min & WB: 5 min \\
\hline Water & Slow & $84 \mathrm{aB}$ & $82 \mathrm{aB}$ & $90 \mathrm{aA}$ \\
\hline SPD & Slow & $84 \mathrm{aA}$ & $83 \mathrm{aA}$ & $65 \mathrm{bB}$ \\
\hline $\mathrm{KNO}_{3}$ & Slow & $67 \mathrm{bA}$ & $60 \mathrm{bB}$ & $59 \mathrm{cB}$ \\
\hline Water & Fast & $83 \mathrm{bB}$ & $90 \mathrm{aA}$ & $83 \mathrm{cB}$ \\
\hline SPD & Fast & $90 \mathrm{aA}$ & $92 \mathrm{aA}$ & $87 \mathrm{bB}$ \\
\hline $\mathrm{KNO}_{3}$ & Fast & 89 aA & $92 \mathrm{aA}$ & $91 \mathrm{aA}$ \\
\hline \multicolumn{5}{|c|}{$\mathrm{B}$} \\
\hline \multirow{2}{*}{\multicolumn{2}{|c|}{ Priming }} & \multirow{2}{*}{ Reheating } & \multicolumn{2}{|c|}{ Drying } \\
\hline & & & Slow & Fast \\
\hline \multicolumn{2}{|c|}{ Water } & Ambient temp & $84 \mathrm{~A}$ & $83 \mathrm{~A}$ \\
\hline \multicolumn{2}{|c|}{ Water } & WB: 2 min & $82 \mathrm{~B}$ & $90 \mathrm{~A}$ \\
\hline \multicolumn{2}{|c|}{ Water } & WB: $5 \mathrm{~min}$ & $90 \mathrm{~A}$ & $83 \mathrm{~B}$ \\
\hline \multicolumn{2}{|c|}{ SPD } & Ambient temp & $84 \mathrm{~B}$ & $90 \mathrm{~A}$ \\
\hline \multicolumn{2}{|c|}{ SPD } & WB: $2 \min$ & $83 \mathrm{~B}$ & $92 \mathrm{~A}$ \\
\hline \multicolumn{2}{|c|}{ SPD } & WB: $5 \mathrm{~min}$ & $65 \mathrm{~B}$ & $87 \mathrm{~A}$ \\
\hline \multicolumn{2}{|c|}{$\mathrm{KNO}_{3}$} & Ambient temp & $69 \mathrm{~B}$ & $89 \mathrm{~A}$ \\
\hline \multicolumn{2}{|c|}{$\mathrm{KNO}_{3}$} & WB: 2 min & $60 \mathrm{~B}$ & $92 \mathrm{~A}$ \\
\hline \multicolumn{2}{|c|}{$\mathrm{KNO}_{3}$} & WB: 5 min & $59 \mathrm{~B}$ & $91 \mathrm{~A}$ \\
\hline
\end{tabular}

Means followed by the same lowercase letter in the column and uppercase letter in the row do not differ by Scott-Knott test at $5 \%$ probability level. efficient for maintaining their physiological quality. Similar results were found by Coelho et al. (2015), who observed that the best drying method for cryopreservation of coffee seeds was the fast drying with silica gel.

Remaining seeds from treatments with a germination percentage below $80 \%$ were submitted to the tetrazolium test. By means of this determination, it was evident that a slow drying is harmful to seeds primed with $\mathrm{KNO}_{3}$, regardless of the reheating method used, since more than $25 \%$ of the seeds were not viable (data not shown). Similarly, tobacco seed priming with spermidine, together with a slow drying and reheating in a 5-minute water bath, was detrimental to seed viability ( $23 \%$ of the seeds were not viable).

Moreover, when seeds were submitted to a slow drying, the best germination rate indices were observed for seeds primed with spermidine, reheated at ambient temperature, and water bathed for two minutes, as well as those primed with water, reheated at ambient temperature, and water bathed for five minutes. For seeds submitted to fast drying, no variation was observed in the germination rate index (Table 5A).

The fast drying of tobacco seeds after priming is more efficient for maintaining physiological quality and vigor

Table 4. Germination (\%) of primed and cryopreserved tobacco (Nicotiana tabacum) seeds of the cultivar BAT 2101 for the factors priming and reheating (A) and drying (B).

\begin{tabular}{|c|c|c|c|c|}
\hline \multicolumn{5}{|c|}{ A } \\
\hline \multirow{2}{*}{ Priming } & \multirow{2}{*}{ Drying } & \multicolumn{3}{|c|}{ Reheating } \\
\hline & & Ambient temp & WB: 2 min & WB: 5 min \\
\hline Water & Slow & $85 \mathrm{bB}$ & $82 \mathrm{bC}$ & $92 \mathrm{aA}$ \\
\hline SPD & Slow & $89 \mathrm{aA}$ & $88 \mathrm{aA}$ & $68 \mathrm{bB}$ \\
\hline $\mathrm{KNO}_{3}$ & Slow & $72 \mathrm{cA}$ & $61 \mathrm{cB}$ & $61 \mathrm{cB}$ \\
\hline Water & Fast & $89 \mathrm{aB}$ & $92 \mathrm{aA}$ & $89 \mathrm{cB}$ \\
\hline SPD & Fast & $91 \mathrm{aB}$ & $88 \mathrm{bC}$ & $96 \mathrm{aA}$ \\
\hline $\mathrm{KNO}_{3}$ & Fast & $91 \mathrm{aA}$ & $93 \mathrm{aA}$ & $92 \mathrm{bA}$ \\
\hline \multicolumn{5}{|c|}{$\mathrm{B}$} \\
\hline \multirow{2}{*}{\multicolumn{2}{|c|}{ Priming }} & \multirow{2}{*}{ Reheating } & \multicolumn{2}{|c|}{ Drying } \\
\hline & & & Slow & Fast \\
\hline \multicolumn{2}{|c|}{ Water } & Ambient temp & $85 \mathrm{~B}$ & $89 \mathrm{~A}$ \\
\hline \multicolumn{2}{|c|}{ Water } & WB: 2 min & $82 \mathrm{~B}$ & $92 \mathrm{~A}$ \\
\hline \multicolumn{2}{|c|}{ Water } & WB: 5 min & $92 \mathrm{~A}$ & $89 \mathrm{~A}$ \\
\hline \multicolumn{2}{|c|}{ SPD } & Ambient temp & $89 \mathrm{~A}$ & $91 \mathrm{~A}$ \\
\hline \multicolumn{2}{|c|}{ SPD } & WB: 2 min & $88 \mathrm{~A}$ & $88 \mathrm{~A}$ \\
\hline \multicolumn{2}{|c|}{ SPD } & WB: 5 min & $68 \mathrm{~B}$ & $96 \mathrm{~A}$ \\
\hline \multicolumn{2}{|c|}{$\mathrm{KNO}_{3}$} & Ambient temp & $72 \mathrm{~B}$ & $91 \mathrm{~A}$ \\
\hline \multicolumn{2}{|c|}{$\mathrm{KNO}_{3}$} & WB: 2 min & $61 \mathrm{~B}$ & $93 \mathrm{~A}$ \\
\hline \multirow{2}{*}{\multicolumn{2}{|c|}{$\mathrm{KNO}_{3}$}} & WB: 5 min & $61 \mathrm{~B}$ & $92 \mathrm{~A}$ \\
\hline & & $\mathrm{CV}(\%)=1$ & & \\
\hline
\end{tabular}

Means followed by the same lowercase letter in the column and uppercase letter in the row do not differ by Scott-Knott test at 5\% probability level. 
of seeds when compared to the slow drying (Table 5B). According to José et al. (2009), among the processes that precede seed conservation, drying has an essential role. However, depending on how it is conducted, it can damage seeds, leading to a reduction in their physiological quality.

The results obtained for the tests of initial and final emergence and emergence rate index are similar to those obtained for germination and germination rate index. In addition, a low percentage of seedlings emerged at the first count from seeds primed with $\mathrm{KNO}_{3}$ and dried slowly, regardless of the reheating method used after cryopreservation (Table 6A). Similarly, priming of seeds with SPD, slow drying, and reheating in a water bath for five minutes had a negative effect on the initial emergence of plants.

A lower percentage of emerged plants at seven days after sowing was observed when the seeds were dried slowly. This result shows the losses of a slow drying to the quality of primed and cryopreserved tobacco seeds (Table 6B).

When seeds were submitted to a slow drying, the highest percentages of final emergence were obtained by means of seeds primed with spermidine and reheated in a water bath for two minutes, as well as by those primed with water and

Table 5. Germination rate index of primed and cryopreserved tobacco (Nicotiana tabacum) seeds of the cultivar BAT 2101 for the factors priming and reheating (A) and drying (B).

\begin{tabular}{|c|c|c|c|c|}
\hline \multicolumn{5}{|c|}{ A } \\
\hline \multirow{2}{*}{ Priming } & \multirow{2}{*}{ Drying } & \multicolumn{3}{|c|}{ Reheating } \\
\hline & & Ambient temp & WB: 2 min & WB: $5 \mathrm{~min}$ \\
\hline Water & Slow & $14.19 \mathrm{aA}$ & $10.33 \mathrm{bB}$ & $16.17 \mathrm{aA}$ \\
\hline SPD & Slow & $16.29 \mathrm{aA}$ & $16.47 \mathrm{aA}$ & $11.42 \mathrm{bB}$ \\
\hline $\mathrm{KNO}_{3}$ & Slow & $11.29 \mathrm{bA}$ & $10.49 \mathrm{bA}$ & $11.17 \mathrm{bA}$ \\
\hline Water & Fast & $14.42 \mathrm{aA}$ & $15.12 \mathrm{aA}$ & $14.46 \mathrm{aA}$ \\
\hline SPD & Fast & $15.38 \mathrm{aA}$ & $15.09 \mathrm{aA}$ & $15.73 \mathrm{aA}$ \\
\hline $\mathrm{KNO}_{3}$ & Fast & $15.20 \mathrm{aA}$ & $16.16 \mathrm{aA}$ & $15.92 \mathrm{aA}$ \\
\hline \multicolumn{5}{|c|}{$\mathrm{B}$} \\
\hline \multirow{2}{*}{\multicolumn{2}{|c|}{ Priming }} & \multirow{2}{*}{ Reheating } & \multicolumn{2}{|c|}{ Drying } \\
\hline & & & Slow & Fast \\
\hline \multicolumn{2}{|c|}{ Water } & Ambient temp & $14.19 \mathrm{~A}$ & $14.42 \mathrm{~A}$ \\
\hline \multicolumn{2}{|c|}{ Water } & WB: 2 min & $10.33 \mathrm{~B}$ & $15.12 \mathrm{~A}$ \\
\hline \multicolumn{2}{|c|}{ Water } & WB: 5 min & $16.17 \mathrm{~A}$ & $14.46 \mathrm{~A}$ \\
\hline \multicolumn{2}{|c|}{ SPD } & Ambient temp & $16.29 \mathrm{~A}$ & $15.38 \mathrm{~A}$ \\
\hline \multicolumn{2}{|c|}{ SPD } & WB: 2 min & $16.47 \mathrm{~A}$ & $15.09 \mathrm{~A}$ \\
\hline \multicolumn{2}{|c|}{ SPD } & WB: 5 min & $11.42 \mathrm{~B}$ & $15.73 \mathrm{~A}$ \\
\hline \multicolumn{2}{|c|}{$\mathrm{KNO}_{3}$} & Ambient temp & $11.29 \mathrm{~B}$ & $15.20 \mathrm{~A}$ \\
\hline \multicolumn{2}{|c|}{$\mathrm{KNO}_{3}$} & WB: 2 min & $10.49 \mathrm{~B}$ & $16.16 \mathrm{~A}$ \\
\hline \multicolumn{2}{|c|}{$\mathrm{KNO}_{3}$} & WB: 5 min & $11.17 \mathrm{~B}$ & $15.92 \mathrm{~A}$ \\
\hline
\end{tabular}

Means followed by the same lowercase letter in the column and uppercase letter in the row do not differ by Scott-Knott test at $5 \%$ probability level. reheated at ambient temperature or water bath for five minutes (Table 7A). When seeds were submitted to a fast drying, those primed with SPD presented good final emergence results for all reheating types, differing from the others. Positive effects of seed priming with SPD have been reported in the literature for other species (Hussain et al., 2015; Paul et al., 2017), confirming the results obtained in our study.

The positive effect of a fast drying after priming on the maintenance of the physiological quality of tobacco seeds for cryopreservation was observed due to a higher percentage of the final emergence of plants coming from seeds dried quickly (Table 7B).

The lowest emergence rate indices were presented by seeds primed with $\mathrm{KNO}_{3}$ and dried slowly, regardless of the type of reheating (Table 8A). Similarly, seeds primed with SPD, dried slowly, and reheated in a water bath for five minutes presented a low emergence rate index when compared to other treatments. No variation was observed in the emergence rate index when the seeds were submitted to a fast drying, except for seeds primed with $\mathrm{KNO}_{3}$ and reheated in a 2-minute water bath, which obtained a lower emergence rate index when compared to the other treatments. The efficiency of $\mathrm{KNO}_{3}$ in

Table 6. Initial emergence (\%) of primed and cryopreserved tobacco (Nicotiana tabacum) seeds of the cultivar BAT 2101 for the factors priming and reheating (A) and drying (B).

\begin{tabular}{|c|c|c|c|c|}
\hline \multicolumn{5}{|c|}{ A } \\
\hline \multirow{2}{*}{ Priming } & \multirow{2}{*}{ Drying } & \multicolumn{3}{|c|}{ Reheating } \\
\hline & & Ambient temp & WB: 2 min & WB: $5 \mathrm{~min}$ \\
\hline Water & Slow & $85 \mathrm{aB}$ & $83 \mathrm{bB}$ & $88 \mathrm{aA}$ \\
\hline SPD & Slow & $84 \mathrm{aB}$ & $88 \mathrm{aA}$ & $66 \mathrm{bC}$ \\
\hline $\mathrm{KNO}_{3}$ & Slow & $56 \mathrm{bB}$ & $57 \mathrm{cB}$ & $59 \mathrm{cA}$ \\
\hline Water & Fast & $88 \mathrm{aA}$ & $91 \mathrm{aA}$ & $89 \mathrm{bA}$ \\
\hline SPD & Fast & $89 \mathrm{aB}$ & $92 \mathrm{aA}$ & $89 \mathrm{bB}$ \\
\hline $\mathrm{KNO}_{3}$ & Fast & $88 \mathrm{aB}$ & $83 \mathrm{bC}$ & $93 \mathrm{aA}$ \\
\hline \multicolumn{5}{|c|}{$\mathrm{B}$} \\
\hline \multirow{2}{*}{\multicolumn{2}{|c|}{ Priming }} & \multirow{2}{*}{ Reheating } & \multicolumn{2}{|c|}{ Drying } \\
\hline & & & Slow & Fast \\
\hline \multicolumn{2}{|c|}{ Water } & Ambient temp & $85 \mathrm{~B}$ & $88 \mathrm{~A}$ \\
\hline \multicolumn{2}{|c|}{ Water } & WB: 2 min & $83 \mathrm{~B}$ & $91 \mathrm{~A}$ \\
\hline \multicolumn{2}{|c|}{ Water } & WB: 5 min & $88 \mathrm{~A}$ & $89 \mathrm{~A}$ \\
\hline \multicolumn{2}{|c|}{ SPD } & Ambient temp & $84 \mathrm{~B}$ & $89 \mathrm{~A}$ \\
\hline \multicolumn{2}{|c|}{ SPD } & WB: 2 min & $88 \mathrm{~B}$ & $92 \mathrm{~A}$ \\
\hline \multicolumn{2}{|c|}{ SPD } & WB: 5 min & $66 \mathrm{~B}$ & $89 \mathrm{~A}$ \\
\hline \multicolumn{2}{|c|}{$\mathrm{KNO}_{3}$} & Ambient temp & $56 \mathrm{~B}$ & $88 \mathrm{~A}$ \\
\hline \multicolumn{2}{|c|}{$\mathrm{KNO}_{3}$} & WB: 2 min & $57 \mathrm{~B}$ & $83 \mathrm{~A}$ \\
\hline \multicolumn{2}{|c|}{$\mathrm{KNO}_{3}$} & WB: 5 min & $59 \mathrm{~B}$ & $93 \mathrm{~A}$ \\
\hline
\end{tabular}

Means followed by the same lowercase letter in the column and uppercase letter in the row do not differ by Scott-Knott test at $5 \%$ probability level. 
Table 7. Final emergence (\%) of primed and cryopreserved tobacco (Nicotiana tabacum) seeds of the cultivar BAT 2101 for the factors priming and reheating (A) and drying (B).

\begin{tabular}{|c|c|c|c|c|}
\hline \multicolumn{5}{|c|}{ A } \\
\hline \multirow{2}{*}{ Priming } & \multirow{2}{*}{ Drying } & \multicolumn{3}{|c|}{ Reheating } \\
\hline & & Ambient temp & WB: 2 min & WB: $5 \mathrm{~min}$ \\
\hline Water & Slow & $87 \mathrm{aB}$ & $84 \mathrm{bC}$ & $90 \mathrm{aA}$ \\
\hline SPD & Slow & $85 \mathrm{bB}$ & $89 \mathrm{aA}$ & $67 \mathrm{bC}$ \\
\hline $\mathrm{KNO}_{3}$ & Slow & $59 \mathrm{cB}$ & $59 \mathrm{cB}$ & $62 \mathrm{cA}$ \\
\hline Water & Fast & $92 \mathrm{aA}$ & $92 \mathrm{aA}$ & $90 \mathrm{cA}$ \\
\hline SPD & Fast & $92 \mathrm{aA}$ & $93 \mathrm{aA}$ & $93 \mathrm{aA}$ \\
\hline $\mathrm{KNO}_{3}$ & Fast & $91 \mathrm{aA}$ & $84 \mathrm{bC}$ & $94 \mathrm{aA}$ \\
\hline \multicolumn{5}{|c|}{$\mathrm{B}$} \\
\hline \multirow{2}{*}{\multicolumn{2}{|c|}{ Priming }} & \multirow{2}{*}{ Reheating } & \multicolumn{2}{|c|}{ Drying } \\
\hline & & & Slow & Fast \\
\hline Water & & Ambient temp & $87 \mathrm{~B}$ & $92 \mathrm{~A}$ \\
\hline Water & & WB: 2 min & $84 \mathrm{~B}$ & $92 \mathrm{~A}$ \\
\hline Water & & WB: 5 min & $90 \mathrm{~A}$ & $90 \mathrm{~A}$ \\
\hline SPD & & Ambient temp & $85 \mathrm{~B}$ & $92 \mathrm{~A}$ \\
\hline SPD & & WB: 2 min & $89 \mathrm{~B}$ & $93 \mathrm{~A}$ \\
\hline SPD & & WB: 5 min & $67 \mathrm{~B}$ & $93 \mathrm{~A}$ \\
\hline $\mathrm{KNO}_{3}$ & & Ambient temp & $59 \mathrm{~B}$ & $91 \mathrm{~A}$ \\
\hline $\mathrm{KNO}_{3}$ & & WB: 2 min & $59 \mathrm{~B}$ & $84 \mathrm{~A}$ \\
\hline $\mathrm{KNO}_{3}$ & & WB: 5 min & $62 \mathrm{~B}$ & $94 \mathrm{~A}$ \\
\hline
\end{tabular}

Means followed by the same lowercase letter in the column and uppercase letter in the row do not differ by Scott-Knott test at 5\% probability level.

priming is possibly related to the presence of $\mathrm{K}^{+}$ions in the cell content. However, because of their low molecular weight, the salts can penetrate seeds and cause toxicity to seedlings.

According to the results of the emergence rate index, the slow drying was harmful to seed physiological quality, especially when the seeds were primed with a $\mathrm{KNO}_{3}$ solution (Table $8 \mathrm{~B}$ ). The slow drying of seeds was also harmful to seeds primed with SPD, dried slowly, and reheated in a water bath for five minutes.

\section{Conclusions}

Priming tobacco seeds can be cryopreserved without physiological quality loss.

Spermidine and water are substances indicated for priming tobacco seeds of the cultivar BAT 2101.

The best drying method for tobacco seeds after priming aiming at cryopreservation is a fast drying with silica gel.

After cryopreservation, the reheating of tobacco seeds in a water bath for two minutes is the most appropriate procedure.
Table 8. Emergence rate index of primed and cryopreserved tobacco (Nicotiana tabacum) seeds of the cultivar BAT 2101 for the factors priming and reheating (A) and drying (B).

\begin{tabular}{|c|c|c|c|c|}
\hline \multicolumn{5}{|c|}{ A } \\
\hline \multirow{2}{*}{ Priming } & \multirow{2}{*}{ Drying } & \multicolumn{3}{|c|}{ Reheating } \\
\hline & & Ambient temp & WB: 2 min & $\mathrm{WB}: 5 \mathrm{~min}$ \\
\hline Water & Slow & $16.70 \mathrm{aA}$ & $16.47 \mathrm{aA}$ & $17.33 \mathrm{aA}$ \\
\hline SPD & Slow & $16.16 \mathrm{aA}$ & $17.13 \mathrm{aA}$ & $12.14 \mathrm{bB}$ \\
\hline $\mathrm{KNO}_{3}$ & Slow & $11.32 \mathrm{bA}$ & $12.87 \mathrm{bA}$ & $11.21 \mathrm{bA}$ \\
\hline Water & Fast & $16.78 \mathrm{aA}$ & $17.07 \mathrm{aA}$ & $17.30 \mathrm{aA}$ \\
\hline SPD & Fast & $17.15 \mathrm{aA}$ & $17.64 \mathrm{aA}$ & $16.39 \mathrm{aA}$ \\
\hline $\mathrm{KNO}_{3}$ & Fast & $16.54 \mathrm{aA}$ & $14.59 \mathrm{bB}$ & $16.94 \mathrm{aA}$ \\
\hline \multicolumn{5}{|c|}{$\mathrm{B}$} \\
\hline \multirow{2}{*}{\multicolumn{2}{|c|}{ Priming }} & \multirow{2}{*}{ Reheating } & \multicolumn{2}{|c|}{ Drying } \\
\hline & & & Slow & Fast \\
\hline $\mathrm{Wa}$ & & Ambient temp & $16.70 \mathrm{~A}$ & $16.78 \mathrm{~A}$ \\
\hline $\mathrm{Wa}$ & & WB: 2 min & $16.47 \mathrm{~A}$ & $17.06 \mathrm{~A}$ \\
\hline $\mathrm{Wa}$ & & WB: 5 min & $17.32 \mathrm{~A}$ & $17.30 \mathrm{~A}$ \\
\hline SP & & Ambient temp & $16.16 \mathrm{~A}$ & $17.15 \mathrm{~A}$ \\
\hline SP & & WB: 2 min & $17.13 \mathrm{~A}$ & $17.64 \mathrm{~A}$ \\
\hline SP & & WB: 5 min & $12.14 \mathrm{~B}$ & $16.39 \mathrm{~A}$ \\
\hline $\mathrm{KN}$ & & Ambient temp & $11.32 \mathrm{~B}$ & $16.54 \mathrm{~A}$ \\
\hline $\mathrm{KN}$ & & WB: 2 min & $12.87 \mathrm{~B}$ & $14.59 \mathrm{~A}$ \\
\hline $\mathrm{KN}$ & & WB: $5 \mathrm{~min}$ & $11.21 \mathrm{~B}$ & $16.94 \mathrm{~A}$ \\
\hline \multicolumn{5}{|c|}{$\mathrm{CV}(\%)=6.50$} \\
\hline
\end{tabular}

Means followed by the same lowercase letter in the column and uppercase letter in the row do not differ by Scott-Knott test at 5\% probability level.

\section{Acknowledgments}

To Coordenação de Aperfeiçoamento de Pessoal de Nivel Superior (CAPES) and Conselho Nacional de Desenvolvimento Cientifico e Tecnológico ( $\mathrm{CNPq})$ for the financial support to carry out this study and for granting the scholarship to the authors, and to the company Souza Cruz for making the seeds available.

\section{References}

BRASIL. Ministério da Agricultura, Pecuária e Abastecimento. Regras para análise de sementes. Ministério da Agricultura, Pecuária e Abastecimento. Secretaria de Defesa Agropecuária. Brasília: MAPA/ACS, 2009. 395p. http://www.agricultura.gov.br/assuntos/ insumos-agropecuarios/arquivos-publicacoes-insumos/2946 regras_analise_sementes.pdf

BRASIL. Instrução Normativa n.45, de 17 de setembro de 2013. Padrões para produção e comercialização de sementes. Diário Oficial da União, Ministério da Agricultura, Pecuária e Abastecimento, Brasília, DF, 20 set. 2013. http:/www.abrasem.com.br/wpcontent/uploads/2012/10/Instru\%C3\%A7\%C3\%A3o-Normativan\%C2\%BA-45-de-17-de-Setembro-de-2013-Padr\%C3\%B5es-deIdentidade-e-Qualiidade-Prod-e-Comerc-de-Sementes-GrandesCulturas-Republica\%C3\%A7\%C3\%A3o-DOU-20.09.13.pdf 
CALDEIRA, C.M.; CARVALHO, M.L.M.; GUIMARÃES, R.M.; COELHO, S.V.B. Physiological priming and pelleting of tobacco seeds. Seed Science and Technology, v.42, n.2, p.180-189, 2014. https://doi.org/10.15258/sst.2014.42.2.07

CASEIRO, R.F.; MARCOS-FILHO, J. Métodos para a secagem de sementes de cebola submetidas ao condicionamento fisiológico. Horticultura Brasileira, v.23, n.4, p.887-892, 2005. http://dx.doi. org/10.1590/S0102-05362005000400005

COELHO, S.V.B.; FIGUEIREDO, M.A.; CLEMENTE, A.C.S.; COELHO, L.F.S.; ROSA, S.D.V.F. Alterações fisiológicas e bioquímicas em sementes de café secas em sílica gel e soluções salinas saturadas. Pesquisa Agropecuária Brasileira, v.50, n.6, p.483491, 2015. http://dx.doi.org/10.1590/S0100-204X2015000600007

FARIA, C.V.N.; PAIVA, R.; FREITAS, R.T.; FIGUEIREDO, J.R.M.; SILVA, D.P.C.; REIS, M.V. Criopreservação de sementes de Physalis angulata L. por meio da desidratação em sílica gel. Plant Cell Culture \& Micropropagation, v.12, n.2, p.27-33, 2016.http://177.105.2.193/ ojs/index.php/PlantCellCultureMicropropagation/article/view/91/48

FERREIRA, D.F. Sisvar: a computer statistical analysis system. Ciência e Agrotecnologia, v.35, n.6, p.1039-1042, 2011. http:// dx.doi.org/10.1590/S1413-70542011000600001

HUSSAIN, S.; ZHENG, M.; KHALIQ, A.; FAHARD, S.; PENG, S.; HUANG, J.; CUI, K.; NIE, L. Benefits of rice priming are offset permanently by prolonged storage and the storage conditions. Scientific reports, v.1, n.1, p.1-12, 2015. https://doi.org/10.1038/srep08101

JOSÉ, S.C.B.R.; SALOMÃO, A.N.; MUNDIM, R.C.; PÁDUA, J.G. Umidificação de sementes de girassol após ultrassecagem em sílica gel e câmara de secagem. Revista Brasileira de Sementes, v.31, p.1626, 2009. http://dx.doi.org/10.1590/S0101-31222009000300002

MAGUIRE, J.D. Speeds of germination aid selection and evaluation for seedling emergence and vigor. Crop Science, v.2, n.2, p.176-177, 1962. https://dl.sciencesocieties.org/publications/ cs/abstracts/2/2/CS0020020176

MAJDI, S.; BARZEGAR, M.; JABBARI, A.; ALIKHANI, M. A. Supercritical fluid extraction of tobacco seed oil and its comparison with solvent extraction methods. Journal of Agricultural Science and Technology, v.14, p.1053-1065, 2012. https://www.cabdirect. org/cabdirect/FullTextPDF/2012/20123314798.pdf

PAUL, S.; ROYCHOUDHURY, A.; BANERJEE, A.; CHAUDHURI, N.; GHOSH, P. Seed pre-treatment with spermidine alleviates oxidative damages to different extent in the salt $(\mathrm{NaCl})-$ stressed seedlings of three indica rice cultivars with contrasting level of salt tolerance. Plant Gene, n.11, p.112-123, 2017. https://doi. org/10.1016/j.plgene.2017.04.002
PÉREZ-RODRÍGUES, J.L.; ESCRIBA, R.C.R.; GONZÁLEZ, G.Y.; OLMEDO, J.L.G.; MARTÍNEZ-MONTEIRO, M.E. Effect of desiccation on physiological and biochemical indicators associated with the germination and vigor of cryopreserved seeds of Nicotiana tabacum L. cv. Sancti Spiritus 96. In Vitro Cellular \& Developmental Biology - Plant, v.53, p.440-448, 2017. https://doi.org/10.1007/ s11627-017-9857-y

REIS, R.G.E.; GUIMARÃES, R.M.; VIEIRA, A.R.; GONÇALVEZ, N.R.; COSTA, V.H. Physiological quality of osmoprimed eggplant seeds. Ciência e Agrotecnologia, v.36, n.5, p.526-532, 2012. http:// dx.doi.org/10.1590/S1413-70542012000500005

RODRIGUES, A.P.D.C.; LAURA, V.A.; PEREIRA, S.R.; FERREIRA, E.; FREITAS, M.E. Armazenamento de sementes de salsa osmocondicionadas. Ciência Rural, v.41, n.6, p.978-983, 2011. http://dx.doi.org/10.1590/S0103-84782011005000069

SEGATO, S.V.; GABALDI, F.C. Fungos associados às sementes de fumo (Nicotiana tabacum L.). Nucleus, v.9, n.2, p.229-234, 2012. http://dx.doi.org/10.3738/nucleus.v9i2.784

TOUCHELL, D.H.; DIXON, K.W. Cryopreservation of seedbanking of Australian species. Annals of Botany, v.74, p.541-546, 1994. https://doi.org/10.1006/anbo.1994.1152.

VARIER, A.; VARI, A.K.; DADLANI, M. The subcellular basis of seed priming. Current Science, v.99, n.4, p.450-456, 2010. http:// www.jstor.org/stable/24109568.

VEIGA-BARBOSA, L.; MIRA, S.; GONZÁLEZ-BENITO, M.E.; SOUZA, M.M.; MELETTI, L.M.M.; PÉREZ'GRACÍA, F. Seed germination, desiccation tolerance and cryopreservation of Passiflora species. Seed Science Technology, v.41, p.89-97, 2013. https://doi. org/10.15258/sst.2013.41.1.08

WEN-GUANG, M.A.; ZHENG, Y.; LI, Y.; NIU, Y.; CHEN, Y. Effects of water priming duration and different drying methods of pelleted seed on germination of tobacco pelleted seeds and seedling growth. Acta Agriculturae Jiangxi, n.7, 2009. http://en.cnki.com.cn/ Article_en/CJFDTOTAL-JXNY200907010.htm. 02 JUL. 2018. 